\title{
CERTOLIZUMAB PEGOL IN PATIENTS WITH RHEUMATOID ARTHRITIS: POOLED EFFICACY ANALYSIS OF PHASE 3 CLINICAL TRIALS ACROSS BASELINE RHEUMATOID FACTOR QUARTILES
}

Yoshiya Tanaka ${ }^{1}$,Zhanguo Li ${ }^{2}$, Nevsun Inanc ${ }^{3}$, Ricardo Machado Xavier ${ }^{4,}$, Nicola Tilt ${ }^{5}$, Carlos Cara ${ }^{5}$, Carine Saadoun ${ }^{5}$, Tsutomu Takeuchi ${ }^{6}$

1.University of Occupational and Environmental Health, Kitakyushu, Japan. 2.Peking University People's Hospital, Beijing, China. 3.Marmara University School of Medicine, Istanbul, Turkey. 4.Universidade Federal do Rio Grande do Sul, Porto Alegre (RS), Brazil. 5.UCB Pharma, Brussels, Belgium. 6.Keio University School of Medicine, Tokyo, Japan.

*Corresponding author: rxavier10@gmail.com

\section{BACKGROUND}

Elevated rheumatoid factor (RF) in patients with rheumatoid arthritis (RA) is considered a risk factor for disease progression1 and is associated with reduced response to antiTNFs.2-3 Certolizumab pegol (CZP), a PEGylated, Fc-free anti-TNF, showed rapid and sustained reduction in signs and symptoms of moderate to severe RA, inhibition of radiographic progression and improvements in physical function in patients with an inadequate response to methotrexate (MTX).4-7 We assess the efficacy of CZP plus MTX in patients with established, active RA across baseline RF levels.

\section{MATERIALS AND METHODS}

Patients with active RA $\geq 6$ months (defined by ACR 1987 criteria) received CZP 200 mg every two weeks (Q2W, CZP 400 mg at weeks 0/2/4) or placebo (PBO) Q2W plus MTX, over 24 weeks. Study design and results were reported previously (RAPID 1 [NCT00152386], RAPID 2 [NCT00175877], J-RAPID [NCT00791999] and RAPID-C [NCT02151851]).4-7 Rheumatoid factor titers were measured by validated assays; patients were classified into: $<25.0, \geq 25.0-<78.5, \geq 78.5-<207.0$ and $\geq 207.0 \mathrm{IU} / \mathrm{mL}$. Disease activity score 28 - erythrocyte sedimentation rate [DAS28(ESR)] categories were adopted to classify patients: remission, <2.6; low disease activity, $\leq 3.2$. Missing values were imputed using LOCF.

\section{RESULTS}

Data were pooled from 1,017 CZP+MTX and 504 PBO+MTX-treated patients. Baseline mean (SD) DAS28(ESR) was similar between groups, across RF quartiles (PBO+MTX: 6.5 [0.9]-7.0 [0.9]; CZP+MTX: 6.6 [0.9]-7.0 [0.9]). Numerically higher response was observed for CZP+MTX vs PBO+MTX at week 24, across RF quartiles (Fig. 1A). CZP+MTX response increased to week 24 (Fig. 1B); the response was generally similar across RF quartiles at all timepoints.
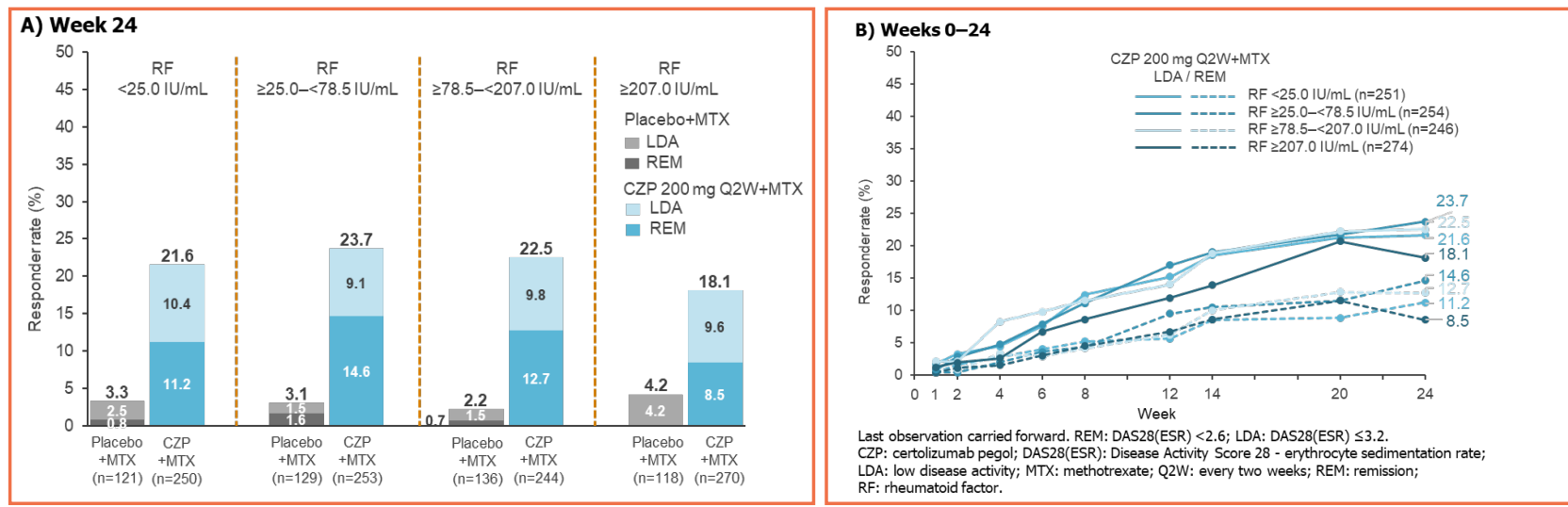

Figure 1. Poole DAS28(ESR) LA and remission rates for CZP+MTX. 


\section{CONCLUSION}

Over 24 weeks, CZP+MTX efficacy was consistent and independent of RF levels; results may be related to the unique molecular structure of CZP. CZP+MTX may be a feasible treatment option in RA irrespective of patients' baseline RF status.

\section{ACKNOWLEDGEMENTS}

This study was funded by UCB Pharma. Editorial services were provided by Costello Medical, Singapore.

\section{REFERENCES}

1. Aletaha D, Alasti F, Smolen JS. Arthritis Res Ther. 2015;17(1):229. https://doi.org/10.1186/s13075-015-0736-9

2. Bobbio-Pallavicini F, Caporali R, Alpini C, Avalle S, Epis OM, Klersy C, et al. High IgA rheumatoid factor levels are associated with poor clinical response to tumour necrosis factor alpha inhibitors in rheumatoid arthritis. Ann Rheum Dis. 2007;66(3):302-7. https://doi.org/10.1136/ $\operatorname{ard} .2006 .060608$

3. Potter C, Hyrich KL, Tracey A, Lunt M, Plant D, Symmons DPM, et al. Association of rheumatoid factor and anti-cyclic citrullinated peptide positivity, but not carriage of shared epitope or PTPN22 susceptibility variants, with anti-tumour necrosis factor response in rheumatoid arthritis. Ann Rheum Dis. 2009;68(1):69-74. https://doi.org/10.1136/ard.2007.084715

4. Keystone E, Van Der Heijde D, Mason Jr. D, Landewè R, Van Vollenhoven R, Combe B, et al. Certolizumab pegol plus methotrexate is significantly more effective than placebo plus methotrexate in active rheumatoid arthritis: Findings of a fifty two-week, phase III, multicenter, randomized, double blind, placebo controlled, parallel group study. Arthritis Rheum. 2008;58(11):3319-29. https://doi.org/10.1002/art.23964

5. Smolen J, Landewè RB, Mease P, Brzezicki J, Madson D, Luijtens K, et al. Efficacy and safety of certolizumab pegol plus methotrexate in active rheumatoid arthritis: the RAPID 2 study. A randomised controlled trial. Ann Rheum Dis. 2009;68(6):797-804. https://doi.org/10.1136/ ard.2008.101659

6. Yamamoto K, Takeuchi T, Yamaka H, Ishiguro N, Tanaka Y, Eguchi K, et al. Efficacy and safety of certolizumab pegol plus methotrexate in Japanese rheumatoid arthritis patients with an inadequate response to methotrexate: The J-RAPID randomized, placebo-controlled trial. Mod Rheumatol. 2014;24(5):715-24. https://doi.org/10.3109/14397595.2013.864224

7. Bi L, Li Y, He X, Xu H, Jiang Z, Wang Y, et al. Efficacy and safety of certolizumab pegol in combination with methotrexate in methotrexateinadequate responder Chinese patients with active rheumatoid arthritis: 24-week results from a randomised, double-blind, placebocontrolled phase 3 study. Clin Exp Rheumatol. 2019;37(2):227-34. 